\title{
Effect of Different Sources of Fertilization on Chemical Properties of Soil Under Cassava Cultivation in Western Pará, Brazil
}

\author{
Marcelo Laranjeira Pimentel ${ }^{1}$, Iolanda Maria Soares Reis ${ }^{1}$, Victor Sousa Portela ${ }^{1}$, \\ Maria Lita Padinha Correa Romano ${ }^{1}$, Carlos Ivan Aguilar Vildoso ${ }^{1}$, Eloi Gasparin ${ }^{1} \&$ Eliandra de Freitas $\mathrm{Sia}^{1}$ \\ ${ }^{1}$ Federal University of Western Pará, Santarém, PA, Brazil \\ Correspondence: Iolanda Maria Soares Reis, Biodiversity and Forest Institute, Federal University of Western Pará, \\ Santarém, PA, Brazil. Tel: 55-93-9229-1367. E-mail: iolandareis@outlook.com
}

Received: June 15, 2020

doi:10.5539/jas.v12n9p106
Accepted: July 17, $2020 \quad$ Online Published: August 15, 2020

URL: https://doi.org/10.5539/jas.v12n9p106

\begin{abstract}
Nutrient management becomes essential in soils with low natural fertility, so the use of organic fertilizers can improve chemical properties of soil and reduce production costs. The objective of this study was to evaluate the effect of different fertilization sources on the chemical properties of soil under cassava cultivation. The experiment was conducted between 2017/2018 in the community of Boa Esperança, Santarém-PA using the cultivar Bem-te-vi, in the randomized block design with 4 treatments: T1 (without fertilization), T2 (fertilization NPK), T3 (organic fertilization with poultry manure), T4 (fertilization with cattle manure), with 5 replicates. The soil samples were analyzed for the contents $\mathrm{K}^{+}, \mathrm{Ca}^{2+}, \mathrm{pH}$ in $\mathrm{H}_{2} \mathrm{O}$ and $\mathrm{KCl}, \mathrm{Al}^{3+}$ and soil organic carbon content (TOC). The data were submitted to analysis of variance and the means were compared by the Tukey test at $5 \%$ probability, using the software MINITAB $^{\odot}$ version 18 . There were statistical differences between the treatments for all the chemical properties analyzed. The findings of the analysis were that fertilization with catle manure and NPK were the same and differed from the other treatments for the contents of $\mathrm{K}^{+}, \mathrm{pH}$ in $\mathrm{H}_{2} \mathrm{O}$ and $\mathrm{KCl}$, for $\mathrm{Ca}^{2+}$ and TOC. The treatment without fertilization obtained the lowest values differing from the others, for $\mathrm{Al}^{+}$. The source from NPK obtained the lowest content in the soil. The treatments with organic fertilizers had higher levels of the above nutrients in the soil. The chemical properties of the soil were altered from the different management systems for the cultivation of cassava.
\end{abstract}

Keywords: organic fertilizers, soil fertility, manioc, catle manure, nutrients

\section{Introduction}

Cassava (Manihot esculenta Crantz.) is native to the southern amazon region of South America. The plant is popularly known in Brazil as "cassava", "macaxeira", or "aipim." It belongs to the family Euphorbiaceae, which is characterized by the presence of glycosides and latex, and number of variable roots (Matos et al., 2016; Torres, 2018). Its roots are rich in carbohydrates and cassava is a staple food in several countries for low-income populations, such as Africa, Asia and Latin America (Alves et al., 2008).

It is one of the most energy-dense foods in the world and it is consumed by more than 700 million people globally because of its ability to adapt to various environmental and climatic conditions, and its density of starch per unit area (Souza et al., 2018; Maxmen, 2019). Cassava is consumed by humans, as well as used in animal feed (Souza et al., 2019) through processed products (farinha, fécula, polvilho, etc.). It is an excellent protein and energy source (Halsey et al., 2008).

In the Amazon, cassava is the majorly produced crop, in terms of net profit, agronomic and sociocultural importance. Cassava is typically sourced from family farms (Rosa et al., 2014). Family farming plays an important role in the Brazil's food supply, contributing about $87 \%$ of the national cassava production (Food and Agriculture Organization of the United Nations [FAO], 2016).

The world production of cassava in 2016 corresponded to 277.1 million tons. Brazil was the fourth largest producer of cassava root production in 2018 reached 17.64 million tons, with an area harvested of 1.20 million hectares and a productivity of 14.63 tons per hectare. The state Pará has highest cassava root production in Brazil, with 3.83 million tons (Instituto Brasileiro de Geografia e Estatística [IBGE], 2018). 
Although cassava can grow in coditions of deficient soil fertility and limited water supply, this crop extracts a large amount of nutrients from the soil, and in subsequent cycles compromises its productivity. Cassava productivity is decreasing predominatly due to two factors: reduced supply of technology and lack of assistance to producers (Alves \& Júnior, 2012).

A limiting factor for agricultural production in Pará is the natural deficiency of the soils, which is correlated to the climate of the region. Additionally, improper management by producers contributes to the deficient soils, which according to Bezerra et al. (2019) occurs because of the non-replacement of nutrients to the soil. According to Brancalião et al. (2015), the adaptations to different soil and climate conditions which producers use for crop management, minimum amounts of inputs or do not use, which depreciates the production potential of the crop.

There are few studies regarding different sources of fertilization for cassava crops, with emphasis on the availability of nutrients in the soil. Studies with this emphasis are vital because in the state of Pará, this is one of the limiting factors for production. Some research shows that cassava crops respond positively to fertilization, which improves nutrient content and crop yield (Odedina et al., 2012).

Therefore, it is necessary to seek out alternative methods of fertilizing the soil with adequate nutrients for sustaining the crop. Hence, the objective of this work was to evaluate the effect of different sources of fertilization on chemical properties of soil used under cassava cultivation in a family farming area in the community of Boa Esperança.

\section{Method}

\subsection{Characterization of the Area and Location of the Experiment}

The study was carried in a small family farm production area, located on the PA 370 road, in Curuá-Una, Santarém-PA-Brazil, in the lower amazon mesoregion, in the community of Boa Esperança under the coordinates $2^{\circ} 44^{\prime} 24.7^{\prime \prime} \mathrm{S}$ and $54^{\circ} 31^{\prime} 33.2^{\prime \prime} \mathrm{W}$ at altitude of 145 a.s.l. The soil of the area is characterized as Yelow Latosol, clayey texture (sand (173 g/kg), silt (168 g/kg) and clay (659 g/kg)) (Santos et al., 2018). The climate of the region is tropical, with well-defined seasons: one dry and another with high rainfall rates, according to the Koppen classification (Andrade \& Corrêa, 2014), with an average annual temperature of $25.5^{\circ} \mathrm{C}$, mean relative humidity $88 \%$ and average annual rainfall of $1.820 \mathrm{~mm}$, with the average temperature of the coldest month higher than $18{ }^{\circ} \mathrm{C}$ (Almeida et al., 2012). The data of monthly mean precipitation, maximum and minimum temperature during the study period are presented in Figure 1.

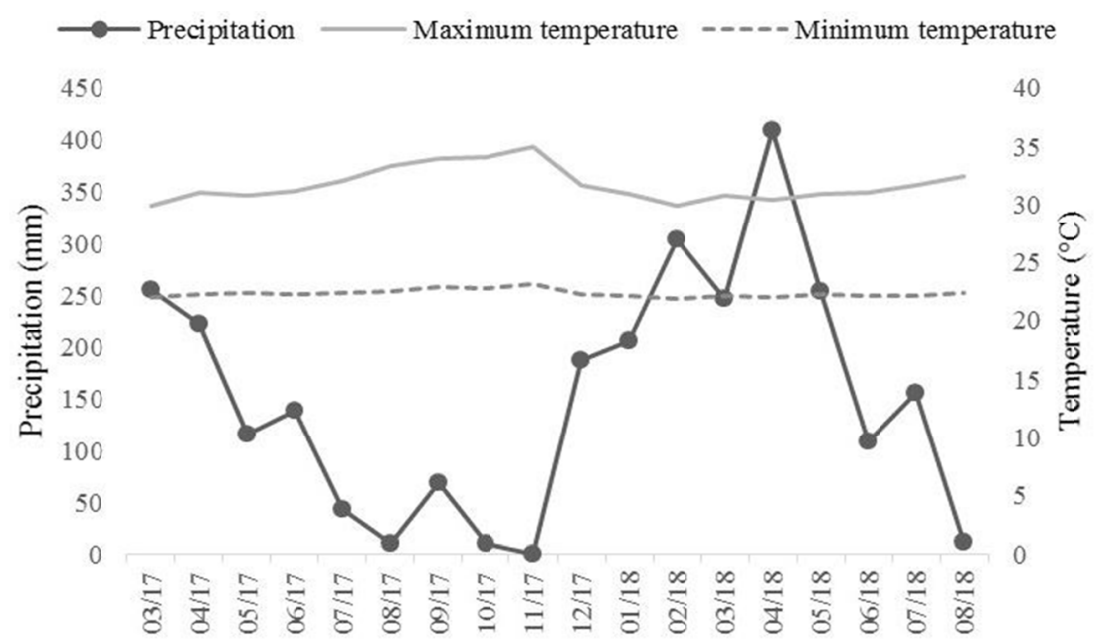

Figure 1. Precipitation values, maximum temperature and minimum temperature during the development of the experiment.

\subsection{Preliminary Preparation}

Before planting, soil samples were collected for initial chemical characterization of fertility, according Teixeira et al. (2017). Based on the results obtained (Table 1) fertilization was performed as per the guideline, described 
in the manual for fertilizer and limiting recommendations for the state of Pará (Embrapa, 2007). Harrowing soil was carried out to improve the physical characteristics.

Table 1. Characterization of soil chemical and physical attributes before cassava planting in the layer $0-20 \mathrm{~cm}$

\begin{tabular}{|c|c|}
\hline Attributes & Layer $0-20 \mathrm{~cm}$ \\
\hline $\mathrm{pH} \mathrm{H}_{2} \mathrm{O}$ & 6.1 \\
\hline $\mathrm{pH} \mathrm{Cacl}{ }_{2}$ & 5.4 \\
\hline $\mathrm{P}\left(\mathrm{mgdm}^{-3}\right)$ & 4.0 \\
\hline $\mathrm{K}\left(\mathrm{mgdm}^{-3}\right)$ & 43.9 \\
\hline $\mathrm{Ca}+\mathrm{Mg}\left(\mathrm{cmol}_{\mathrm{C}} \mathrm{Kg}^{-1}\right)$ & 4.6 \\
\hline $\mathrm{Ca}\left(\mathrm{cmol}_{\mathrm{c}} \mathrm{Kg}^{-1}\right)$ & 3.4 \\
\hline $\mathrm{Mg}\left(\mathrm{cmol}_{\mathrm{c}} \mathrm{Kg}^{-1}\right)$ & 1.2 \\
\hline $\mathrm{Al}\left(\mathrm{cmol}_{\mathrm{C}} \mathrm{Kg}^{-1}\right)$ & 0.0 \\
\hline $\mathrm{H}\left(\mathrm{cmol}_{\mathrm{c}} \mathrm{Kg}^{-1}\right)$ & 4.0 \\
\hline $\mathrm{OM}\left(\mathrm{gKg}^{-1}\right)$ & 37.8 \\
\hline $\mathrm{SB}\left(\mathrm{cmol}_{\mathrm{c}} \mathrm{dm}^{-3}\right)$ & 4.8 \\
\hline $\mathrm{CEC}\left(\mathrm{cmol}_{\mathrm{c}} \mathrm{dm}^{-3}\right)$ & 8.7 \\
\hline $\mathrm{V}(\%)$ & 54.5 \\
\hline $\mathrm{m}(\%)$ & 0.0 \\
\hline sat $\mathrm{Ca}(\%)$ & 39.0 \\
\hline sat $\mathrm{Mg}(\%)$ & 14.3 \\
\hline sat K (\%) & 1.3 \\
\hline sat H $(\%)$ & 45.5 \\
\hline $\mathrm{Ca} / \mathrm{Mg}$ & 2.7 \\
\hline $\mathrm{Ca} / \mathrm{K}$ & 29.8 \\
\hline $\mathrm{Mg} / \mathrm{K}$ & 11.0 \\
\hline Sand (g/Kg) & 173.0 \\
\hline Silt (g/Kg) & 168.0 \\
\hline Clay (g/Kg) & 659.0 \\
\hline
\end{tabular}

Note. $\mathrm{P}=$ phosporus; $\mathrm{K}=$ potassium; $\mathrm{Ca}=$ calcium; $\mathrm{Mg}=$ magnesium; $\mathrm{Al}=$ aluminum $; \mathrm{H}=$ hydrogen; $\mathrm{OM}=$ organic matter content; $\mathrm{SB}=$ sum of bases; $\mathrm{CEC}=$ cationic Exchange Capacity; $\mathrm{V}=$ base saturation; $\mathrm{m}=$ aluminum saturation; sat $\mathrm{Ca}=$ saturation by $\mathrm{Ca}$; sat $\mathrm{Mg}$ = saturation by $\mathrm{Mg}$; sat $\mathrm{K}$ = saturation by $\mathrm{K}$; sat $\mathrm{H}=$ saturation by $\mathrm{H}$.

\subsection{Source of Cassava and Planting}

The experiment was conducted with cassava (Manihot esculenta Crantz.), being the cultivar used Bem-te-vi, which is also managed by the producers at the site. The genetic material was made available by the community's own producers, and the best materials were selected to conduct the experiment. The planting was carried in the 2017/18 agricultural year, using the spacing of $1 \times 1 \mathrm{~m}$.

\subsection{Conducting the Experiment and Treatments}

The design used was randomized blocks, four treatments in 5 blocks, totaling 20 plots, each plot had $6 \times 6 \mathrm{~m}$, totaling $36 \mathrm{~m}^{2}$ per plot. In treatment 1 (T1), this sample was without fertilization, treatment 2 (T2) this sample was the fertilization with NPK formulation (40-80-60), this fertilization was performed as recommended in the Manual of fertilization and liming of the state of Pará (Embrapa, 2007), treatment 3 (T3) this sample was the organic fertilization with poultry manure, being $11 \mathrm{~kg} / \mathrm{plot}$ and for treatment 4 (T4) this sample was the organic fertilization with cattle manure, it was used of $16 \mathrm{~kg} / \mathrm{plot}$.

At 450 days after planting, 10 random simple samples were removed from each experimental plot to form 1 sample composed per plot, totaling 20 samples composed at the depth of 0-20 cm, Dutch auger was used. Five samples composed by treatment were collected, for further analysis of the chemical properties of the soil.

\subsection{Soil Chemical Analysis}

Soil chemical analysis was performed at the Soil Quality Laboratories and Soil Laboratory of the Federal University of Western Pará, according to the recommendation of the Manual of soil analysis methods (Teixeira et 
al., 2017). The $\mathrm{pH}$ in $\mathrm{H}_{2} \mathrm{O}$ and $\mathrm{KCl}$; determination of the exchangeable cations $\mathrm{Al}^{3^{+}}$and $\mathrm{Ca}^{2+}$ extracted with $\mathrm{KCl}$ 1 mol L ${ }^{-1}$ using complexometry method; $\mathrm{K}^{+}$extracted by Mehlich-1 solution and the total soil organic carbon (TOC) content was determined by the wet pathway method, through the oxidation of organic matter by potassium dichromate.

\subsection{Statistical Analysis}

The data were submitted to variance analysis and the averages of treatments compared by tukey test at $5 \%$ probability, the statistical software used was Minitab ${ }^{\odot}$ version 18 (Minitab, 2018).

\section{Results and Discussion}

The effects of different sources of fertilization on soil chemical properties at 450 days of cassava cultivation are presented in Table 2.

Table 2. Analysis of the average of soil chemical characteristics from treatments with fertilization depth (0-20 $\mathrm{cm})$

\begin{tabular}{|c|c|c|c|c|c|c|c|}
\hline \multirow{2}{*}{ Treatments } & \multicolumn{2}{|c|}{$\mathrm{pH}$} & \multirow{2}{*}{$\begin{array}{l}\mathrm{Al} \\
\mathrm{cmol}_{\mathrm{c}} \mathrm{kg}^{-1}\end{array}$} & \multirow{2}{*}{$\frac{\mathrm{K}}{\mathrm{mgdm}^{-3}}$} & $\mathrm{Ca}$ & $\mathrm{Mg}$ & \multirow{2}{*}{$\frac{\text { TOC }}{\mathrm{g} \mathrm{kg}^{-1}}$} \\
\hline & $\mathrm{H}_{2} \mathrm{O}$ & $\mathrm{KCl}$ & & & \multicolumn{2}{|c|}{----- cmol$_{\mathrm{c}} \mathrm{kg}^{-1}$----- } & \\
\hline No fertilizing & $4.96 \mathrm{~B}$ & $4.35 \mathrm{~B}$ & $0.46 \mathrm{~A}$ & $20.24 \mathrm{C}$ & $3.78 \mathrm{~B}$ & $0.92 \mathrm{~A}$ & $19.82 \mathrm{~B}$ \\
\hline $\mathrm{N}-\mathrm{P}-\mathrm{K}$ fertilization & $5.22 \mathrm{AB}$ & $4.68 \mathrm{~A}$ & $0.22 \mathrm{~B}$ & $30.13 \mathrm{AB}$ & $5.70 \mathrm{~A}$ & $1.56 \mathrm{~A}$ & $21.01 \mathrm{AB}$ \\
\hline Poultry manure & $4.99 \mathrm{~B}$ & $4.28 \mathrm{~B}$ & $0.41 \mathrm{AB}$ & $22.68 \mathrm{BC}$ & $4.24 \mathrm{AB}$ & $1.00 \mathrm{~A}$ & $21.11 \mathrm{AB}$ \\
\hline Cattle manure & $5.53 \mathrm{~A}$ & $4.52 \mathrm{AB}$ & $0.38 \mathrm{AB}$ & $33.95 \mathrm{~A}$ & $5.62 \mathrm{~A}$ & $1.22 \mathrm{~A}$ & $21.95 \mathrm{~A}$ \\
\hline C.V. (\%) & 3.47 & 3.60 & 31.34 & 17.32 & 18.02 & 38.36 & 2.83 \\
\hline
\end{tabular}

Note. $\mathrm{Al}=$ aluminum; $\mathrm{K}=$ potassium; $\mathrm{Ca}=$ calcium; $\mathrm{Mg}=$ magnesium; $\mathrm{TOC}=$ total organic carbon; $\mathrm{C} . \mathrm{V} .=$ coefficient of variation. Averages followed by equal letters in the same column do not differ from each other according to the Tukey test $(p \leq 0.05)$.

For the test of comparison of means of potassium content present in the soil from different sources of fertilization, it is noted that the treatment with cattle manure and mineral fertilization with NPK were statistically equal, differing from the other treatments, according to the identified in Table 2.

However, a reduction in the soil $\mathrm{K}^{+}$content was observed at the end of the experiment, which may be related to the absorption rate of this element by the plants or through the leaching process due to the high rainfall rates during the experiment. Werle et al. (2008) states that there is a reduction in soil potassium content, mainly in soils with high initial levels of this element, due to the percolation process in the soil.

The fertilization with cattle manure provided the highest absolute potassium content in the final evaluation period of the experiment, being statistically equal to the fertilization with NPK. According to Nascimento et al. (2017), organic fertilization increases the concentration of cationic nutrients, such as $\mathrm{K}^{+}$in the root absorption zone of plants, increasing the intake of this nutrient in the soil. In fact, the slow decomposition of cattle manure reduces the loss of $\mathrm{K}^{+}$that is not used by the plant, resulting in nutrient input in the soil, since the accumulation of $\mathrm{K}^{+}$from NPK, indicated that the plant was unable to use large quantities of this element from this source, which accumulated on the surface of the clayey soil, due to easy availability and adsorption in the soil.

Similar results were found by Júnior et al. (2014), where an increase in $\mathrm{K}^{+}$content was verified in the soil, under the addition of organic material. The use of cattle manure in fertilization allows the improvement of soil quality, increases nutrient recycling and provides the reduction of mineral fertilizers (Higashikawa \& Júnior, 2017), reducing the cost of production.

Organic fertilization with poultry waste showed low values when comparing fertilization with cattle manure, obtaining an average value of $22.68 \mathrm{mg} \mathrm{dm}^{-3}$ of $\mathrm{K}^{+}$for this treatment, this is considered low (Embrapa, 2007), as identified in Table 2. Thus, it is possible to infer that there was loss of the nutrient by leaching or is related to the greater extraction of $\mathrm{K}^{+}$from this source for production, since this is one of the nutrients extracted in greater amounts by cassava crop, as observed by Rós et al. (2013) in an experiment with cassava under different doses of cattle manure.

After comparing the initial $\mathrm{pH}$ value of the soil before cultivation (Table 1) and after the cultivation of cassava, there was an observable reduction in $\mathrm{pH}$ values, making the soil more acidic and increasing the $\mathrm{Al}^{3^{+}}$values that were previously null. Similar results were observed by Guimarães et al. (2015), where after the cultivation of 
cassava, the $\mathrm{pH}$ of the soil tended to acidify. This was already observed in studies carried out by Betencourt et al. (2012). The reduction in $\mathrm{pH}$ values tends to be related to the plant's ability to extract more nutrients with rhizosphere acidification, however, Sarr et al. (2013) observed a reduction in $\mathrm{pH}$ with the cultivation of cassava, and associated this acidification with the accumulation of organic matter.

Regarding the analysis of soil $\mathrm{pH}$ between the evaluated treatments, significant differences were observed ( $\mathrm{p} \leq$ 0.05 ), both for $\mathrm{pH}$ in water and for $\mathrm{pH}$ in $\mathrm{KCl}$. For $\mathrm{pH}$ in water, treatment with cattle manure and NPK fertilization obtained the highest $\mathrm{pH}$ values, being statistically equal, for the treatment of poultry manure and the treatment without fertilization, there were no statistical differences between them, obtaining the lowest values for $\mathrm{pH}$ in water, being respectively 4.99 and 4.96, considered acidic, according to Table 2 .

According to Balerini et al. (2018), the use of organic fertilizers tends to increase soil $\mathrm{pH}$ in relation to a natural soil without the addition of organic fertilizers. Santos et al. (2017), states that the reduction of $\mathrm{pH}$ in a soil without the addition of organic fertilizer is related to the natural condition of the soil, and to dynamic root systems, which corroborates the data presented.

The increase in the $\mathrm{pH}$ value of cattle manure may be related to the increase in organic matter and to the lower soil $\mathrm{Al}^{3^{+}}$content. According to Medina et al. (2018), as the $\mathrm{pH}$ increases, the number of negative charges increases, and as the $\mathrm{pH}$ decreases, there is an increase in the number of positive charges.

The $\mathrm{pH}$ range in $\mathrm{KCl}$, according to the data found, were considered low, but there were differences between the means for treatments, NPK fertilization and cattle manure differed from treatments without fertilization and poultry manure (Table 2).

It was observed that the $\mathrm{pH}$ range in water was higher than the $\mathrm{pH}$ range in $\mathrm{KCl}$. Similar results were found by Nascimento et al. (2017), indicating the predominance of negative charges, which is related to cation adsorption.

After comparing the $\mathrm{Al}^{3^{+}}$levels before the cassava planting (Table 1) and after planting, there was an increase in the exchangeable aluminum contents of the soil, which is related to its greater solubilization due to the reduction of the initial $\mathrm{pH}$ values of the experiment. Therefore, the reduction of the $\mathrm{pH}$ values for the soil, increased the aluminum contents during the experiment.

In order to evaluate the contents of exchangeable aluminum $\left(\mathrm{Al}^{3^{+}}\right)$, between treatments, the treatments with cattle manure, poultry manure and without fertilization were statistically equal, differing only from the treatment with NPK fertilization, which obtained the lowest mean of $\mathrm{Al}^{3^{+}}$. The highest aluminum content was found in the treatment without fertilization $\left(0.46 \mathrm{Cmol}_{\mathrm{c}} \mathrm{kg}_{-}{ }^{1}\right)$, followed by poultry manure and cattle manure. The values found were considered average for this element in the soil (Embrapa, 2007).

The $\mathrm{Al}^{3^{+}}$levels found for the treatments are related to the values for $\mathrm{pH}$, according to Cunha et al. (2015) the values of $\mathrm{Al}^{3^{+}}$found in the soil are directly related to the increase or reduction of soil $\mathrm{pH}$, and the lower content of $\mathrm{Al}^{3^{+}}$is related to higher $\mathrm{pH}$ values, and higher Levels of $\mathrm{Al}^{3^{+}}$are related to more acidic soils, which may cause toxicity in plants, as observed in Table 2.

The data found for $\mathrm{Ca}^{2+}$ contents show that the treatments regardless of fertilization increased the levels of macronutrient in the soil, as these differed in relation to the treatment without fertilization, according to Table 2. $\mathrm{Ca}^{2^{+}}$values were considered high (Embrapa, 2007).

The highest calcium content was directly related to NPK fertilization and cattle manure, similar results were found by Fidalski (1999). When working with NPK dosages observed an increase in the content of $\mathrm{Ca}^{2+}$ in the soil. It must be considered that the increase in $\mathrm{Ca}^{2+}$ levels by chemical fertilization in the soil must be the result of an indirect effect (Pinheiro et al., 2019), such as liming.

However, fertilization with cattle manure and poultry manure positively affected the availability of $\mathrm{Ca}^{2+}$ contents in the soil, although the treatment with the highest concentration in the final evaluation period was cattle manure. This result differs from a study conducted by Abreu et al. (2010), where a higher concentration of calcium in the soil was observed from the use of poultry manure in relation to fertilization with cattle manure.

For $\mathrm{Mg}^{2+}$ analysis under the different management systems, there were no significant differences between the treatments evaluated, however, the values for this variable were considered average, according to Embrapa (2007).

In the analysis of organic carbon content (TOC), a higher concentration was observed from the use of fertilization with organic sources. The fertilization with cattle manure provided the highest organic carbon content in the soil. 
According to Pinto et al. (2012), the addition of organic residues in the soil in crop systems causes an increase in soil organic matter. Therefore, the addition of organic sources has a high capacity to increase the soil's organic carbon stock, due to the entry of organic matter, in addition to increasing the availability of nutrients.

Steiner et al. (2012), states that the soil organic carbon stock can be altered with greater or lesser intensity, as it is one of the most sensitive properties affected by management descisions. A reduction in the initial content for this element was observed from the planting of cassava, according to Yada et al. (2015), the low levels for this element are related to the removal of the natural cover from the soil for the farm, reducing the capacity of recovery of soil chemical characteristics.

For the mean comparison test, it was observed that there were statistical differences between treatments, and the treatment without fertilization differed from the other treatments, obtaining lower average levels of organic carbon (19.82 $\left.\mathrm{g} \mathrm{kg}^{-1}\right)$, while for the other treatments had no statistical differences. Therefore, organic fertilization has the ability to increase the organic carbon intake of the soil, in relation to fertilization with mineral sources (Table 2).

According to Castoldi et al. (2011), organic fertilization can partially or totally supply mineral fertilizer when managed properly, reducing production costs. Troleis et al. (2017) states that the consumption of mineral fertilizers of high solubility and reduced conditioning action of soil quality, causes increased costs, and alternative sources of fertilization should be evaluated, these allow the improvement of characteristics of the soil.

The values for organic carbon were considered low, and the highest average was presented by fertilization from cattle manure $\left(21.95 \mathrm{~g} \mathrm{~kg}^{-1}\right)$ due to the higher concentration of cellulose in the composition, these characteristics may be related to the degradation processes of organic matter.

The soil organic matter content is related to the environmental conditions present (Paterson \& Sim, 2013), being controlled by rates of decomposition, and renewal of waste, which occur dynamically (Mulvaney et al., 2010). This mainly occurs in soils of tropical regions, due to warmer weather conditions and high rainfall rates, which tends to increase the decomposition of organic matter at an accelerated rate (Barbieri et al., 2013).

\section{Conclusions}

The chemical properties of the soil were altered from the different management systems for the cultivation of cassava.

The use of bovine manure promoted a significant increase in the soil fertility, nutrients, and chemical properties and reduction of acidity in the final evaluation period of the experiment.

Organic fertilizers promoted an increase in soil nutrient content when compared to mineral fertilizers.

Organic fertilizers can replace mineral fertilizers for cassava crop prodution under the conditions which the experiment was conducted.

\section{References}

Abreu, I. M. O., Junqueira, A. M. R., Peixoto, J. R., \& Oliveira, S. A. (2010). Qualidade microbiológica e produtividade de alface sob adubação química e orgânica. Ciência e Tecnologia de Alimentos, 30(1), 108-118. https://doi.org/10.1590/S0101-20612010000500018

Almeida, L. S., Gama, J. R. V., Oliveira, F. A., Carvalho, J. O. P., Gonçalves, D. C. M., \& Araújo, G. C. (2012). Fitossociologia e uso múltiplo de espécies árbóreas em floresta manejada, comunidade Santo Antônio, município de Santarém, estado do Pará. Acta Amazonica, 42(2), 185-194. https://doi.org/10.1590/ S0044-59672012000200002

Alves, J. M. A., Costa, F. A., Uchoa, S. C. P., Santos, C. S. V., Albuquerque, J. A. A., \& Rodrigues, G. S. (2008). Avaliação de dois clones de mandioca em duas épocas de colheita. Revista Agroambiente Online, 2(2), 15-24. https://doi.org/10.18227/1982-8470ragro.v2i2.244

Alves, R. N. B., \& Júnior, M. S. M. (2012). Custo e rentabilidade do processamento de farinha de tapioca no distrito de americano, no município de Santa Isabel, Pará. Amazônia: Ciência e Desenvolvimento, 8(15), 91-102. Retrieved from https://www.alice.cnptia.embrapa.br/handle/doc/968570

Andrade, S. C. P., \& Corrêa, J. A. J. (2014). Estimativa do saldo de radiaçãoinstantâneo à superfície para a cidade de Santarém-PA, através de imagens do Landsat 5-TM. Revista Brasileira de Geografia Física, 7(4), 653-661. Retrieved from https://periodicos.ufpe.br/revistas/rbgfe/article/view/233265 
Balerini, F., Bissani, C. A., Martins, A. P., Arnuti, F., Boettcher, G. N., \& Schwarz, S. F. (2018). Elementos-traço no perfil do solo de pomar cítrico após adubação orgânica de longo prazo. Revista Brasileira de Tecnologia Agropecuária, 2(1), 01-10. Retrieved from http://revistas.fw.uri.br/index.php/rbdta/article/view/2880

Barbieri, D. M., Júnior, J. M., Pereira, G. T., JR, N. L. S., Siqueira, D. S., \& Panosso, A. R. (2013). Comportamento dos óxidos de ferro da fração argila e do fósforo adsorvido, em diferentes sistemas de colheita de cana-de-açúcar. Revista Brasileira de Ciência do Solo, 37(6), 1557-1568. https://doi.org/ 10.1590/S0100-06832013000600012

Betencort, E., Duputel, M., Colomb, B., Desclaux, D., \& Hinsinger, P. (2012). Intercropping promotes the ability of durum wheat and chickpea to increase rhizosphere phosphorus availability in a low P soil. Soil Biology and Biochemistry, 46, 181-190. https://doi.org/10.1016/j.soilbio.2011.11.015

Bezerra, C. B. Júnior, A. J. S., Corrêa, M. M., Lima, J. R. S., Santoro, K. R., Souza, E. S., ... Oliveira, C. L. (2019). Latossolo húmico sob pastagem com diferentes intensidades de usos: atributos químicos e físico-hídricos. Revista Brasileira de Ciências Agrárias, 14(1), 1-9. https://doi.org/10.5039/agraria. v14i1a5603

Brancalião, S. R. Campos, M., \& Bicudo, S. J. (2015). Crescimento e desenvolvimento de plantas de mandioca em função da calagem e adubação com zinco. Nucleus, 12(2), 175-182. https://doi.org/10.3738/1982. 2278.1103

Castoldi, G., Pivetta, L. A., Steiner, F., Costa, M. M. S. C., \& Costa, L. A. M. (2011). Sistema de produção e sua influência na cultura do milho safrinha em plantio direto. Scientia Agraria Paranaensis, 10(1), 47-57. Retrieved from http://e-revista.unioeste.br/index.php/scientiaagraria/article/view/5269

Cunha, G. O. M., Almeida., J. A, Testoni, S. A., \& Barboza, B. B. (2015). Formas de alumínio em solos ácidos brasileiros com teores excepcionalmente altos de $\mathrm{Al}^{3^{+}}$extraível com KCL. Revista Brasileira de Ciência do Solo, 39(5), 1362-1377. https://doi.org/10.1590/01000683rbcs20150017

EMBRAPA (Empresa Brasileira de Pesquisa Agropecuária). (2007). Recomendações de adubação e calagem para o estado do Pará (p. 262).

FAO (Food and Agriculture Organization of the United Nations). (2016). Retrieved from http://www.fao.org/ family-farming/detail/en/c/454156

Fidalski, J. (1999). Resposta da mandioca à adubação NPK e calagem em solos arenosos no Noroeste do Paraná. Pesquisa Agropecuária Brasileira, 34(8), 1353-1359. https://doi.org/10.1590/S0100-204X1999000800005

Guimarães, B. V. C., Fernandes, J. C., Donato, S. L. R., Souza, E. B., \& Guimarães, M. M. C. (2015). Atributos químicos de um espodossolo ferrocárbico no sistema indígena de produção de mandioca. Enciclopedia Biosfera, 11(22), 376-386. https://doi.org/10.18677/Enciclopedia_Biosfera_2015_091

Halsey, M. E., Olsen, K. M., Taylor, N. J., \& Aguirre, P. C. (2008). Reproductive biology of Cassava (Manihot esculenta Crantz) and isolation of experimental field trials. Crop Sciences, 48(1), 49-58. https://doi.org/ 10.2135/cropsci2007.05.0279

Higashikawa, F. S., \& Júnior, F. O. G. M. (2017). Adubação mineral, orgânica e organomineral: Efeito na nutrição, produtividade, pós-colheita da cebola e na fertilidade do solo. Revista Scientia Agraria, 18(2), 01-10. https://doi.org/10.5380/rsa.v18i2.51219

IBGE (Instituto Brasileiro de Geografia e Estatística). (2018). Retrieved from https://www.ibge.gov.br/ estatisticas-novoportal/economicas/agricultura-epecuaria/9107

Júnior, F. O. G. M., Gonçalves, P. A. S., \& Neto, J. V. (2014). Produtividade da cebola em cultívo mínimo no sistema convencional e orgânico com biofertilizantes. Horticultura Brasileira, 32(4), $475-481$. https://doi.org/10.1590/S0102-053620140000400017

Matos, F. S., Felicio, R., Silveira, P. S., Guimarães, R. R., Santos, P. G. F., Nascente, A. C. S., ... Silva, L. M. (2016). Produtividade de cultivares de mandioca sob déficit hídrico. Revista Agries, 2(1). Retrieved from https://revista.unitins.br/index.php/agri-environmental-sciences/article/view/186

Maxmen, A. (2019). The quest to build a better cassava. Nature, 565, 144-146. https://doi.org/10.1038/ d41586-019-00014-2

Medina, E. F., Pires, J. M. M., Oliveira, F. S. D., \& Silva, B. E. C. (2018). Seleção de solos da região de Viçosa para utilização como barreira para metais pesados. The journal of Engineering and Exact Sciences, 4(3), 1-4. https://doi.org/10.18540/jcecvl4iss3pp0349-0352 
Minitab Statistical Software. (2018). Minitab Inc.: State College, PA, USA. Retrieved from https://www.minitab. $\mathrm{com} / \mathrm{pt}-\mathrm{br}$

Mulvaney, M. J., Wood, C. W., Balkcom, K. S., Shannon, D. A., \& Kemble, J. M. (2010). Carbon and nitrogen mineralization and persistence of organic residues under conservation and conventional tillage. Agronomy Journal, 102(5), 1425-1433. https://doi.org/10.2134/agronj2010.0129

Nascimento, E. P., Campos, M. C. C., Alho, L. C., Silva, D. M. P., Weckher, F. C., Mantovanelli, B. C., \& Cunha, J. M. (2017). Crescimento das mudas de cupuaçú (Theobroma glandiflorum) sob efeito de diferentes composições de biofertilizantes. Revista da Universidade Vale do Rio Verde, 15(2), 861-870. https://doi.org/10.5892/ruvrd.v15i2.3299

Nascimento, J. A. M., Souto, J. S., Cavalcante, L. F., Medeiros, S. A. S., \& Pereira, W. E. (2017). Produção de melancia em solo adubado com esterco bovino e potássio. Revista Brasileira de Ciências Agrárias, 12(2), 122-127. https://doi.org/10.5039/agraria.v12i2a5427

Odedina, J. N., Ojeniyi, S. O., \& Odedina, S. A. (2012). Integrated nutrient management for sustainable cassava production in South Western Nigeria. Archives of Agronomy and Soil Science, 58(1), 132-140. https://doi.org/10.1080/03650340.2012.695865

Paterson, E., \& Sim, A. (2013). Soil-especific response functions of organic matter mineralization to the availability of labile carbon. Global Change Biology, 19(5), 1562-1571. https://doi.org/10.1111/gcb.12140

Pinheiro, R. C., Pereira, J. L., \& Rezende, C. F. A. (2019). Adubação biológica associada a adubação química nos parâmetros de solo, nutricional e produtivo do milho. Revista Brasileira de Agropecuária Sustentável, 9(4), 9-17. https://doi.org/10.21206/rbas.v9i04.8459

Pinto, F. A., Santos, F. L., Terra, F. D., Ribeiro, D. O., Sousa, R. R. J., Souza, E. D., ... Paulino, H. B. (2012). Atributos de solo sob pastejo rotacionado em função da aplicação de cama de peru. Pesquisa Agropecuária Tropical, 42(3), 254-262. https://doi.org/10.1590/S1983-40632012000300002

Rós, A. B., Hirata, A. C. S., \& Narita, N. (2013). Produção de raízes de mandioca e propriedades química e física do solo em função de adubação com esterco de galinha. Pesquisa Agropecuária Tropical, 43(3), $247-254$. https://doi.org/10.1590/S1983-40632013000300001

Rosa, J. M. O., Oliveira, S. A., Jordão, A. L., Siviero, A., \& Oliveira, C. M. G. (2014). Nematoides fitoparasitas associados à mandioca na Amazônia brasileira. Acta Amazonica, 44(2), 271-275. https://doi.org/10.1590/ S0044-59672014000200013

Santos, H. G., Jacomine, P. K. T., Anjos, L. H. C., Oliveira, V. A., Lubreras, J. F., Coelho, M. R., ... Cunha, T. L. F. (2018). Sistema brasileiro de classificação de solos (5th ed., p. 356).

Santos, L. H., Canton, L., Ventura, B. S., Ferreira, G. W., Kurtz, C., Brunetto, G., ... Loss, A. (2017). Chemical properties in macroaggregates of a humic dystrudept cultivated with onion under no-till and convencional tillage systems. Revista Brasileira de Ciência do Solo, 41, 1-13. https://doi.org/10.1590/18069657 rbcs20160419

Sarr, P. S., Araki, S., \& Njukwe, E. (2013). Interactions between cassava varieties and soil characteristics in crop production in Eastern Cameroon. African Study Monographs, 34(4), 187-202. https://oi.org/10.14989/ 185093

Souza, F. V. A., Ribeiro, S. C. A., Silva, F. L., \& Teodósio, A. E. M. M. (2019). Resíduos da mandioca em agroindústrias familiares no Nordeste do Pará. Revista Verde, 14(1), 92-98. https://doi.org/10.18378/ rvads.v14i1.6006

Souza, L. P. N., Pereira, B. F. F., Oliveira, I. J., Tucci, C. A. F., \& Nascimento, J. P. (2018). Adubação fosfatada e potássica: Efeito na altura da planta e no diâmtro do caule de mandioca. Revista Terceira margem Amazonia, 3(11). Retrieved from http://www.revistaterceiramargem.com/index.php/terceiramargem/article/view/248

Steiner, F., Pivetta, L. A., Zoz, T., \& Junior, A. S. P. (2012). Estoque de carbono orgânicono solo afetado por adubação orgânica e sistemas de culturas no Sul do Brasil. Semina: Ciências Agrárias, 33(1), 2775-2788. https://doi.org/10.5433/1679-0359.2012v33Supl1p2775

Teixeira, P. C., Donagemma, G. K., Fontana, A., \& Teixeira, W. G. (2017). Manual de métodos e análise de solo (p. 573). Brasília, Brazil.

Torres, V. S. (2018). Relações de espécies botânicas empregadas nos templos de Umbanda Nagô. Unisanta Bioscience, 7(2), 153-190. Retrivied from https://periodicos.unisanta.br/index.php/bio/article/view/1166 
Troleis, M. J. B., Roque, C. G., Borges, M. C. R. Z., Noguerira, K. B., \& Gouveia, N. A. (2017). Estabilidade de agregados e teor de matéria orgânica em um latossolo vermelho sob Urochloa brizantha após aplicação de cama de peru. Revista de Agricultura Neotropical, 4(1), 83-87. https://doi.org/10.32404/rean.v4i1.1267

Werle, R., Garcia, R. A., \& Rosolem, C. A. (2008). Lixiviação de potássio em função da textura e da disponibilidade de nutriente no solo. Revista Brasileira de Ciência do Solo, 32(6), 2297-2305. https://doi.org/10.1590/S0100-06832008000600009

Yada, M. M., Mingotte, F. L. C., Melo, W. J., Melo, G. P., Melo, V. P., Longo, P. M., \& Ribeiro, A. I. (2015). Atributos químicos e bioquímicos em solos degradados por mineração de estanho e em fase de recuperação em ecossistema amazônico. Revista Brasileira de Ciência do Solo, 39(3), 714-724. https://doi.org/ $10.1590 / 01000683$ rbcs20140499

\section{Copyrights}

Copyright for this article is retained by the author(s), with first publication rights granted to the journal.

This is an open-access article distributed under the terms and conditions of the Creative Commons Attribution license (http://creativecommons.org/licenses/by/4.0/). 